Meta-Analysis

\title{
Prognostic significance of anti-diabetic medications in pancreatic cancer: A meta-analysis
}

\author{
Dong-Chu Zhou ${ }^{1,2}$, Hui Gong ${ }^{1,2}$, Chong-Qing $\operatorname{Tan}^{1,2}$ and Jian-Quan Luo ${ }^{1,2}$ \\ ${ }^{1}$ Department of Pharmacy, The Second Xiangya Hospital, Central South University, Changsha, Hunan 410011, China \\ ${ }^{2}$ Institute of Clinical Pharmacy, Central South University, Changsha, Hunan 410011, China \\ Correspondence to: Jian-Quan Luo, email: Ivojianquanxy@csu.edu.cn \\ Dong-Chu Zhou, email: zdc3404@sohu.com \\ Keywords: anti-diabetic medications, pancreatic cancer, prognosis, mortality, meta-analysis \\ Received: January 21, $2017 \quad$ Accepted: April 15, $2017 \quad$ Published: May 09, 2017
}

Copyright: Zhou et al. This is an open-access article distributed under the terms of the Creative Commons Attribution License 3.0 (CC BY 3.0), which permits unrestricted use, distribution, and reproduction in any medium, provided the original author and source are credited.

\section{ABSTRACT}

The role of anti-diabetic medications in pancreatic cancer remains conflicting. We carried out a systematic search of Pubmed and Embase databases for studies published before August 2016, which assessed the associations between anti-diabetic medications (metformin, sulfonylureas, thiazolidinediones and insulin) intake and pancreatic cancer prognosis. Hazard ratios (HRs) with $95 \%$ confidence intervals (CIs) were estimated using the random-effects model. The primary outcomes of interest were overall survival (OS) and progression-free survival (PFS). Fourteen studies enrolling 94778 participants were eligible for inclusion, with 12 cohort studies and 2 randomized controlled trials (RCTs). Significant association between metformin (adjusted $\mathrm{HR}=0.77,95 \% \mathrm{CI}=0.68-0.87$ ) use and $\mathrm{OS}$ was found in cohort studies, whereas no significant association between metformin use and PFS (HR=1.22; 95\% $\mathrm{CI}=0.76-1.95)$ or $\mathrm{OS}(\mathrm{HR}=1.20,95 \% \mathrm{CI}=0.84-1.72)$ in $\mathrm{RCTs}$. No significant survival benefits were identified for insulin $(H R=1.18,95 \% C I=0.83-1.69)$, sulfonylureas $(\mathrm{HR}=1.03,95 \% \mathrm{CI}=0.81-1.30)$, or thiazolidinediones $(\mathrm{HR}=0.84,95 \% \mathrm{CI}=0.58-1.22)$. The trim-and-fill method and subgroup analyses stratified by the study characteristics confirmed the robustness of the results. Our findings provide strong evidence that metformin is associated with improved OS in pancreatic cancer patients in cohort studies. However, the effect of other anti-diabetic medications should be interpreted with caution owing to the limited number of studies.

\section{INTRODUCTION}

Pancreatic cancer $(\mathrm{PC})$ is the fourth leading cause of cancer-related death in the United States [1]. Owing to late stage at the time of diagnosis, there are just $10 \%-20 \%$ of patients eligible for surgical treatment [2]. Although the surgical procedure of pancreatic cancer over the last decades has improved strongly, it needs some more effective treatments and adjuvant therapies against PC.

The relationship between $\mathrm{PC}$ and diabetes mellitus (DM) has been increasingly recognized over the past decades. Studies suggest that DM plays a pivotal role in cancer risk and progression [3-5]. Although we have not fully understood the mechanisms of increased risk of cancer incidence with DM, hyperinsulinemia may influence the neoplastic process through its effects on enhancing cancer cell proliferation, survival, and invasion and inhibiting apoptosis in the insulin-like growth factor-I (IGF-I) signaling pathway [6, 7]. There are an increasing number of experimental evidence and epidemiologic studies to show that ADMs may modify the prognosis of PC. Some studies suggest that metformin may improve outcome of patients with diabetes and pancreatic cancer [8-13], whereas others have not revealed beneficial effect [14-18]. Besides, some studies suggest that insulin may highlight risk of PC mortality [19, 20], whereas others have not affected the survival $[8,11]$. Due to controversial results among studies, we thus carry out this meta-analysis to investigate the prognostic value of ADMs use (as compared with non-user) among PC patients. 


\section{RESULTS}

\section{Description of the included studies}

The initial database search yielded a total of 3326 references for eligibility. After excluding the duplicates and screening the remaining title and abstract, 42 potentially relevant studies were identified for further review. After selection, a total of 14 publications met our inclusion criteria (Figure 1). The clinical features of included studies were summarized in Table 1. In summary, 13 studies investigated the survival outcomes for patients of metformin use, 5 for insulin use, 2 for SUs use and 2 for TZDs use. The median follow-up time ranged from 0.77 to 12 years. 5 studies were carried out in USA, 3 in Europe and 2 in Asia. Several cohorts were adjusted for some conventional influential factors, including age, sex, disease stage. Six studies involved PC patients with I-IV disease stages, and two with stage IV. Assessment of methodological quality for cohort studies yielded a score range of 7 to 9 , and 7 of 12 studies had a score of 8 or above (Supplementary Table 1).

\section{Metformin use and PC survival}

The combined HR for the OS comparing metformin use versus non-use was $0.77(95 \% \mathrm{CI}=0.68-0.87)$ with moderate inter-study heterogeneity $\left(\mathrm{I}^{2}=52.9 \%, \mathrm{p}=0.02\right)$ (Figure 2A) for cohort studies. Figure 2B presents the HR $(\mathrm{HR}=1.22 ; 95 \% \mathrm{CI}=0.76-1.95)$ for PFS. No significant

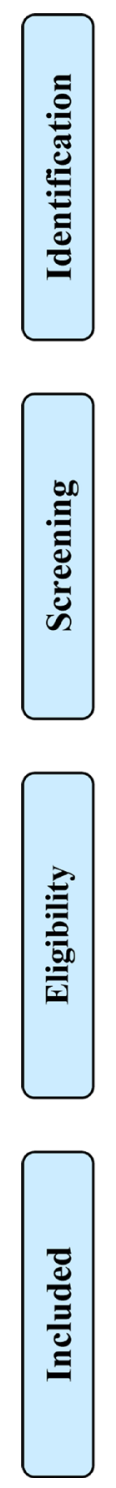

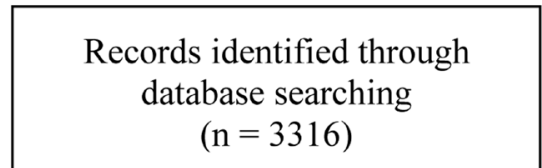

$(\mathrm{n}=3316)$

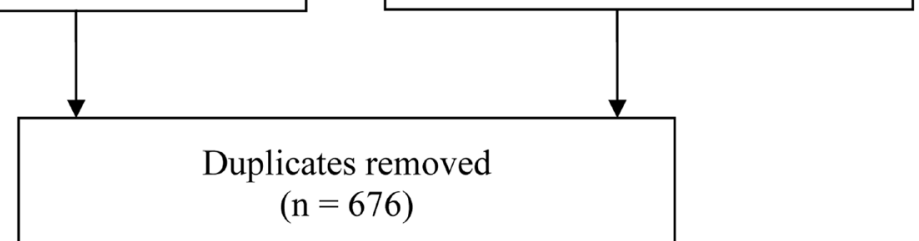

Additional records identified through other sources $(\mathrm{n}=10)$

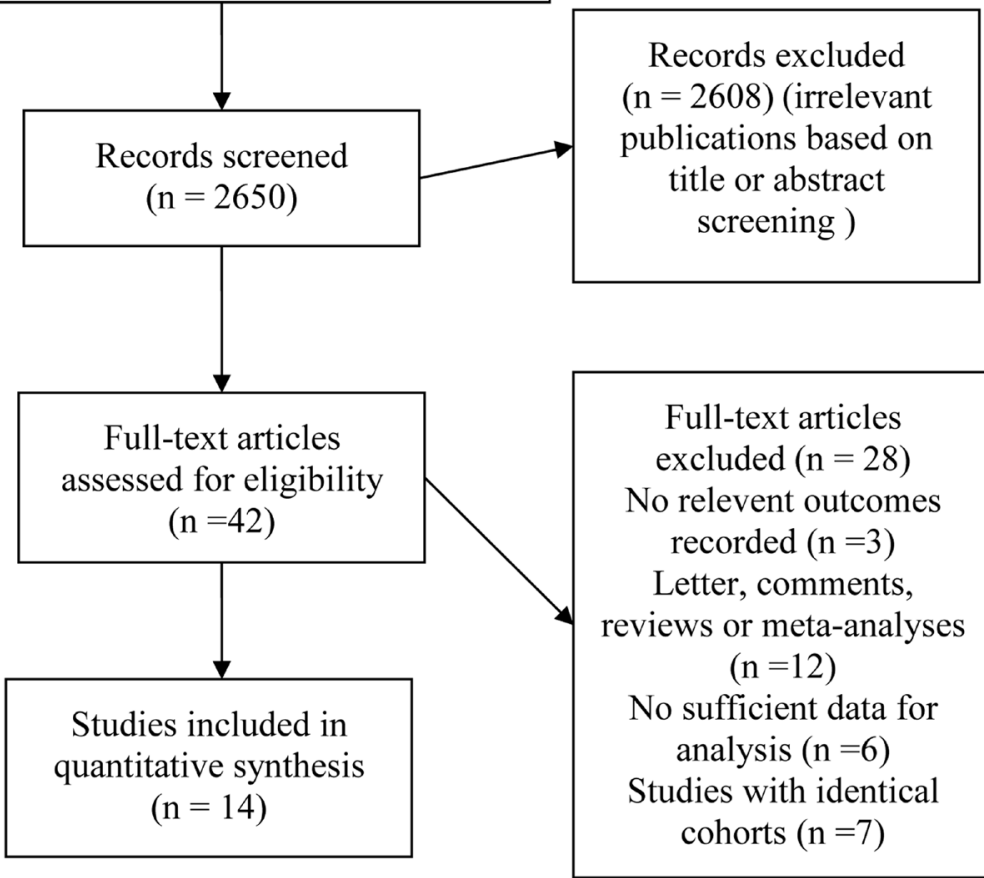

Figure 1: Flow diagram of the selection process of studies investigating effect of anti-diabetic medications use on pancreatic cancer survival. 
Table 1: Baseline characteristics of the included studies on survival outcomes of anti-diabetic medications use for pancreatic cancer patients

\begin{tabular}{|c|c|c|c|c|c|c|c|c|c|c|c|c|}
\hline Authors & Study design & $\begin{array}{l}\text { Country/ } \\
\text { Setting }\end{array}$ & $\begin{array}{l}\text { No. of } \\
\text { hospitals } \\
\text { involved }\end{array}$ & $\begin{array}{l}\text { Study } \\
\text { period }\end{array}$ & $\begin{array}{l}\text { Exposure } \\
\text { ascertainment }\end{array}$ & $\begin{array}{c}\text { Median } \\
\text { follow- } \\
\text { up } \\
\text { (months) }\end{array}$ & $\begin{array}{c}\text { ADMs } \\
\text { user/ } \\
\text { non-user }\end{array}$ & $\begin{array}{c}\text { Sample } \\
\text { size }\end{array}$ & $\begin{array}{l}\text { Types of } \\
\text { ADMs }\end{array}$ & $\begin{array}{c}\text { Disease } \\
\text { stage }\end{array}$ & $\begin{array}{c}\text { Survival } \\
\text { end } \\
\text { points }\end{array}$ & Adjusted variables \\
\hline Reni et al. & RCT & $\begin{array}{l}\text { Italy; } \\
\text { hospital } \\
\text { based }\end{array}$ & Single & $2010-2014$ & RCT & NR & $31 / 29$ & 60 & Metformin & IV & OS, PFS & NR \\
\hline Lee et al. & $\begin{array}{l}\text { Retrospective } \\
\text { cohort }\end{array}$ & $\begin{array}{l}\text { Korea; } \\
\text { hospital } \\
\text { based }\end{array}$ & Single & $2005-2013$ & $\begin{array}{l}\text { Medical } \\
\text { records, } \\
\text { self-reported }\end{array}$ & 10.3 & $117 / 120$ & 237 & $\begin{array}{l}\text { Metformin } \\
\text { TZDs } \\
\text { SU } \\
\text { insulin }\end{array}$ & I-IV & OS & $\begin{array}{l}\text { CA199 levels, tumor } \\
\text { size and stage, } \\
\text { performance status, } \\
\text { DDP4 inhibitors }\end{array}$ \\
\hline Kozak et al. & $\begin{array}{l}\text { Retrospective } \\
\text { cohort }\end{array}$ & $\begin{array}{l}\text { USA; } \\
\text { hospital } \\
\text { based }\end{array}$ & Single & $1998-2013$ & $\begin{array}{l}\text { Electronic } \\
\text { medical } \\
\text { records }\end{array}$ & 11.23 & $18 / 153$ & 171 & Metformin & I-IV & $\begin{array}{l}\text { OS, } \\
\text { DFS }\end{array}$ & $\begin{array}{l}\text { Age, sex, smoking } \\
\text { status, surgery, tumor } \\
\text { stage, treatment } \\
\text { regimen }\end{array}$ \\
\hline Choi et al. & $\begin{array}{l}\text { Retrospective } \\
\text { cohort }\end{array}$ & $\begin{array}{l}\text { Korea; } \\
\text { hospital } \\
\text { based }\end{array}$ & Single & $2003-2010$ & $\begin{array}{l}\text { Electronic } \\
\text { medical } \\
\text { records }\end{array}$ & 10.2 & $56 / 127$ & 183 & $\begin{array}{l}\text { Metformin } \\
\text { SU } \\
\text { insulin }\end{array}$ & I-IV & OS & $\begin{array}{l}\text { Performance status, } \\
\text { diabetes, cancer } \\
\text { extent, weight loss } \\
\text { during therapy }\end{array}$ \\
\hline $\begin{array}{l}\text { Chaiteerakij } \\
\text { et al. }\end{array}$ & $\begin{array}{l}\text { Retrospective } \\
\text { cohort }\end{array}$ & $\begin{array}{l}\text { USA; } \\
\text { hospital } \\
\text { based }\end{array}$ & Single & $2000-2011$ & $\begin{array}{l}\text { Electronic } \\
\text { medical } \\
\text { records }\end{array}$ & 9.26 & $366 / 614$ & 980 & Metformin & I-IV & OS & $\begin{array}{l}\text { Age, sex, BMI, } \\
\text { stage }\end{array}$ \\
\hline $\begin{array}{l}\text { Cerullo } \\
\text { et al. }\end{array}$ & $\begin{array}{l}\text { Retrospective } \\
\text { cohort }\end{array}$ & $\begin{array}{l}\text { USA; } \\
\text { population } \\
\text { based }\end{array}$ & Multiple & 2010-2012 & $\begin{array}{l}\text { Electronic } \\
\text { medical } \\
\text { records }\end{array}$ & 16.5 & $456 / 2937$ & 3393 & Metformin & I-IV & OS & $\begin{array}{l}\text { Age, sex, region, } \\
\text { Charlson index, } \\
\text { treatment regimen }\end{array}$ \\
\hline Ambe et al. & $\begin{array}{l}\text { Prospective } \\
\text { cohort }\end{array}$ & $\begin{array}{l}\text { USA; } \\
\text { hospital } \\
\text { based }\end{array}$ & Single & $1986-2013$ & $\begin{array}{l}\text { Electronic } \\
\text { medical } \\
\text { records }\end{array}$ & 19 & $19 / 25$ & 44 & Metformin & I-II & OS & $\begin{array}{l}\text { Age, BMI, surgery, } \\
\text { diabetes, CA199 } \\
\text { levels, stage, regional } \\
\text { nodes }\end{array}$ \\
\hline $\begin{array}{l}\text { Kordes } \\
\text { et al. }\end{array}$ & $\mathrm{RCT}$ & $\begin{array}{l}\text { Netherlands; } \\
\text { hospital } \\
\text { based }\end{array}$ & Multiple & $2010-2014$ & $\mathrm{RCT}$ & 28.1 & $61 / 60$ & 121 & Metformin & IV & OS, PFS & $\begin{array}{l}\text { Age, sex, } \\
\text { performance status, } \\
\text { stage, tumor location, } \\
\text { surgery, diabetes }\end{array}$ \\
\hline Tseng et al. & $\begin{array}{l}\text { Retrospective } \\
\text { cohort }\end{array}$ & $\begin{array}{l}\text { China; } \\
\text { population } \\
\text { based }\end{array}$ & Multiple & $1995-2006$ & $\begin{array}{l}\text { Structured } \\
\text { questionnaire } \\
\text { interview }\end{array}$ & 12 years & $5927 / 80970$ & 86897 & Insulin & I-IV & OS & $\begin{array}{l}\text { Age, sex, diabetes, } \\
\text { BMI, smoking, } \\
\text { region }\end{array}$ \\
\hline $\begin{array}{l}\text { Hwang } \\
\text { et al. }\end{array}$ & $\begin{array}{l}\text { Retrospective } \\
\text { cohort }\end{array}$ & $\begin{array}{l}\text { United } \\
\text { Kingdom; } \\
\text { population } \\
\text { based }\end{array}$ & Multiple & $2003-2010$ & $\begin{array}{l}\text { Electronic } \\
\text { medical } \\
\text { records }\end{array}$ & NR & $247 / 269$ & 516 & Metformin & I-IV & OS & $\begin{array}{l}\text { Age, sex, diabetes } \\
\text { duration and } \\
\text { complications, } \\
\text { Charlson index, } \\
\text { BMI, GFR, smoking, } \\
\text { other ADMs and } \\
\text { HbA1c. }\end{array}$ \\
\hline $\begin{array}{l}\text { Sadeghi } \\
\text { et al. }\end{array}$ & $\begin{array}{l}\text { Retrospective } \\
\text { cohort }\end{array}$ & $\begin{array}{l}\text { USA; } \\
\text { hospital } \\
\text { based }\end{array}$ & Single & 2000-2009 & $\begin{array}{l}\text { Interviews, } \\
\text { medical } \\
\text { records. }\end{array}$ & 11.4 & $117 / 185$ & 302 & Metformin & I-IV & OS & $\begin{array}{l}\text { Disease stage, } \\
\text { CA199 level, } \\
\text { tumor size and site, } \\
\text { performance status }\end{array}$ \\
\hline Amin et al. & $\begin{array}{l}\text { Retrospective } \\
\text { cohort }\end{array}$ & $\begin{array}{l}\text { USA; } \\
\text { population } \\
\text { based }\end{array}$ & Multiple & $2007-2011$ & NR & NR & $589 / 258$ & 847 & Metformin & I-IV & OS & $\begin{array}{l}\text { Demographic } \\
\text { factors, stage, } \\
\text { income, diabetic } \\
\text { complications, } \\
\text { Charlson index, other } \\
\text { ADMs }\end{array}$ \\
\hline Jang et al. & $\begin{array}{l}\text { Prospective } \\
\text { cohort }\end{array}$ & $\begin{array}{l}\text { Korea; } \\
\text { population } \\
\text { based }\end{array}$ & Multiple & 2005-2011 & $\begin{array}{l}\text { Prescription } \\
\text { information }\end{array}$ & NR & $530 / 234$ & 764 & Metformin & I-IV & OS & NR \\
\hline Jeon et al. & $\begin{array}{l}\text { Retrospective } \\
\text { cohort }\end{array}$ & $\begin{array}{l}\text { USA; } \\
\text { population } \\
\text { based }\end{array}$ & Multiple & 2008-2009 & NR & NR & $132 / 131$ & 263 & $\begin{array}{l}\text { Insulin/ } \\
\text { SUs; } \\
\text { metformin/ } \\
\text { TZDs }\end{array}$ & I-IV & OS & $\begin{array}{l}\text { Age, sex, race, } \\
\text { stage and } \\
\text { chemotherapy }\end{array}$ \\
\hline
\end{tabular}

ADMs, anti-diabetic medications; BMI, body mass index; DFS, disease-free survival; NR, not reported; OS, overall survival; PFS, progression-free survival; RCT, randomized controlled trial; SUs, sulfonylureas; TZDs, thiazolidinediones. 
survival benefit was noted for randomized controlled trials (RCTs) $(\mathrm{HR}=1.20,95 \% \mathrm{CI}=0.84-1.72)$.

We summarized the subgroup analyses for OS in Table 2 to further test potential sources of heterogeneity among certain major clinical characteristics of the included studies. The pooled HRs for the majority of the subgroups did not change significantly stratified by some major study characteristics, including the study design and setting, study country, the number of hospitals, sample size, adjusted variables or the scores of NewcastleOttawa Quality Assessment Scale. A possible interaction was found in the subgroup of sample size. Results of
Study

Lee (2016)

Kozak (2016)

Choi (2016)

Chaiteerakij (2016)

Cerullo (2016)

Ambe (2016)

Hwang (2013)

Sadeghi (2012)

Amin (2015)

Jang (2016)

Jeon (2014)

Random effects model

Heterogeneity: I-squared $=52.9 \%, p=0.0195$
Hazard Ratio
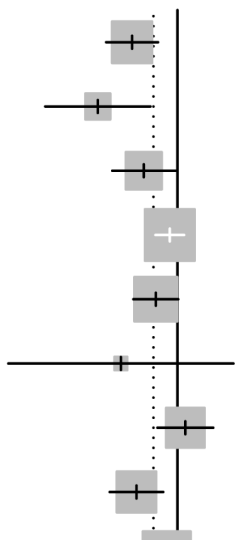

$0.77[0.68 ; 0.87]$

$9.8 \%$

$0.42[0.24 ; 0.75] \quad 3.8 \%$

0.69 [0.49;0.98] $\quad 7.9 \%$

$0.92[0.79 ; 1.08] \quad 15.1 \%$

$0.79[0.62 ; 1.01] \quad 11.2 \%$

$0.54[0.16 ; 1.84] \quad 1.0 \%$

$1.09[0.80 ; 1.48] \quad 9.0 \%$

$0.64[0.48 ; 0.86] \quad 9.5 \%$

$0.89[0.74 ; 1.07] \quad 14.0 \%$

$0.73[0.61 ; 0.87] \quad 14.2 \%$

$0.80[0.48 ; 1.33] \quad 4.5 \%$

$100 \%$
Study

Reni (2016)

Kozak (2016)

Kordes (2015)

Random effects model

Heterogeneity: I-squared $=52.8 \%, p=0.1202$
Hazard Ratio

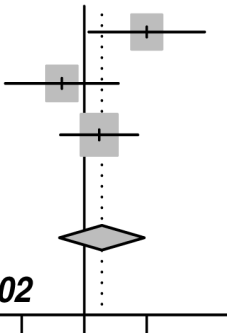

0.512
HR 95\%-Cl W(random)

$2.00[1.05 ; 3.80] \quad 29.0 \%$

$0.78[0.42 ; 1.46] \quad 29.7 \%$

$1.18[0.77 ; 1.81] \quad 41.3 \%$

0.05

B

Figure 2: Meta-analysis of the associations between metformin use and pancreatic cancer overall survival (A), and progression-free surival (B). CI, confidence interval; HR, hazard ratio; W (random): Weights (random effects model). 
Table 2: Subgroup analyses of the associations between metformin use and overall survival for cohort studies

\begin{tabular}{|c|c|c|c|c|}
\hline \multirow{2}{*}{ Comparison variables } & \multicolumn{4}{|c|}{ Overall survival } \\
\hline & No. of studies & $\mathrm{I}^{2}$ statistics; \% & HR (95\% CI) & $\boldsymbol{P}_{\text {interation }}$ \\
\hline Total & 11 & 52.9 & $0.77(0.68-0.87)$ & NA \\
\hline Study design & & & & 0.534 \\
\hline Prospective cohort & 2 & 0 & $0.72(0.61-0.86)$ & \\
\hline Retrospective cohort & 9 & 58.9 & $0.78(0.67-0.90)$ & \\
\hline Study setting & & & & 0.111 \\
\hline Hospital based & 6 & 64.5 & $0.67(0.53-0.85)$ & \\
\hline Population based & 5 & 33.6 & $0.84(0.73-0.96)$ & \\
\hline Study region & & & & 0.214 \\
\hline USA & 7 & 47.2 & $0.78(0.67-0.92)$ & \\
\hline Europe & 1 & & $1.09(0.80-1.48)$ & \\
\hline Asia & 3 & 0 & $0.69(0.60-0.79)$ & \\
\hline Hospital number & & & & 0.111 \\
\hline Single & 6 & 64.5 & $0.67(0.53-0.85)$ & \\
\hline Multiple & 5 & 33.6 & $0.84(0.73-0.96)$ & \\
\hline Sample size & & & & 0.0024 \\
\hline$\geq 500$ & 5 & 44.1 & $0.86(0.76-0.97)$ & \\
\hline$<500$ & 6 & 0 & $0.63(0.54-0.74)$ & \\
\hline Main variable adjusted* & & & & 0.276 \\
\hline Yes & 5 & 57.8 & $0.83(0.68-1.03)$ & \\
\hline No & 6 & 30.8 & $0.73(0.64-0.83)$ & \\
\hline NOS scale & & & & 0.359 \\
\hline$\geq 8$ & 6 & 59.4 & $0.73(0.59-0.90)$ & \\
\hline$<8$ & 5 & 36.2 & $0.82(0.71-0.94)$ & \\
\hline
\end{tabular}

CI, confidence interval; HR, hazard ratio; Main variable adjusted*, Age, sex, stage; NA; not available.

analyses limited to studies with some of the main variable adjusted (age, sex and tumor stage) are also presented in Table 2. For studies with these three variables adjusted, a null prognostic association of metformin use was noted. Nevertheless, further studies should be conducted to examine the true survival benefit of metformin in PC patients due to the small number of studies involved in these subgroups.

Sensitivity analysis by omitting one single study each time and pooling the others indicated that the pooled HRs was not significantly altered. Funnel plot for publication bias did not show asymmetry (Figure 3).
Further Egger's test $(P=0.135)$ or Begg's test $(P=0.436)$ also did not found a certain degree publication bias.

\section{Other ADMs use and PC survival}

Five studies investigated the impact of insulin use and PC survival and there was no significant association between insulin use and $\mathrm{PC}$ survival $(\mathrm{HR}=1.18,95 \%$ $\mathrm{CI}=0.83$-1.69; Figure 4A). We also did not find significant association between SUs (HR $=1.03,95 \% \mathrm{CI}=0.81-1.30$; Figure $4 \mathrm{~B})$ or TZDs $(\mathrm{HR}=0.84,95 \% \mathrm{CI}=0.58-1.22$; Figure 4C) use and PC survival. 


\section{DISCUSSION}

This meta-analysis investigated the association between ADMs (metformin, insulin, SUs and TZDs) treatment and survival of PC. We found metformin treatment was significantly associated with favorable OS of $\mathrm{PC}$ patients $(\mathrm{HR}=0.77,95 \% \mathrm{CI}=0.68-0.87)$ in cohort studies, but was not significantly associated with PFS $(\mathrm{HR}=1.22 ; 95 \% \mathrm{CI}=0.76-1.95)$ for RCTs. We also found no survival benefits of other ADMs, such as insulin, SUs or TZDs, for PC patients.

Several potential mechanisms may explain the associations for the fact that conventional ADMs may alter the risk of multiple malignancies. It was reported that metformin has been shown to play an important anticancer role in multiple ways including insulindependent or independent manners [21]. A recent study found that SUs can induce cell proliferation and had an effect of carcinogenesis by promoting insulin secretion [22]. Moreover, previous in vitro studies showed that TZDs had an impact on cell growth arrest and apoptosis and the inhibition of cancer cell invasion [23].

Several important strengths of this meta-analysis should be addressed. Firstly, to the best of our knowledge, this is the first systematic review regarding the associations between the use of ADMs and prognosis of PC. Secondly, comprehensive and reproducible search strategies were developed to identify all relevant studies or trials in the major databases without language limitations. Thirdly, we investigated the most commonly used ADMs including metformin, SUs, TZDs and insulin and conducted a metaanalysis for both RCTs and cohort studies. Fourthly, more than 90000 participants were included to quantitatively assess the association between ADMs use and PC prognosis, which was the most comprehensive synthesis of the evidence on this topic ever today. Finally, several subgroup analyses were carried out for some of the important variables, such as study design and setting, research region, number of research hospital, main variable adjusted and quality score. The results showed consistency across subgroups.

Still there are limitations in our systematic review. Firstly, the number of studies for each medication involved in this meta-analysis was relatively small except for metformin, and thus it is difficult to draw definite conclusions for the limited statistical power in SUs, TZDs or insulin subset. Secondly, almost none of the included studies had dose or duration-response analysis for certain ADMs, so it is impossible for us to perform this kind of analysis. Therefore, further study should be focused on this aspect. Thirdly, although some major confounders including age, sex and disease stage were identified and adjusted for some of the included studies, some other variables (such as tumor size, body mass index or chemotherapy) could influence our exploration of associations between ADMs and PC survival. Last but not

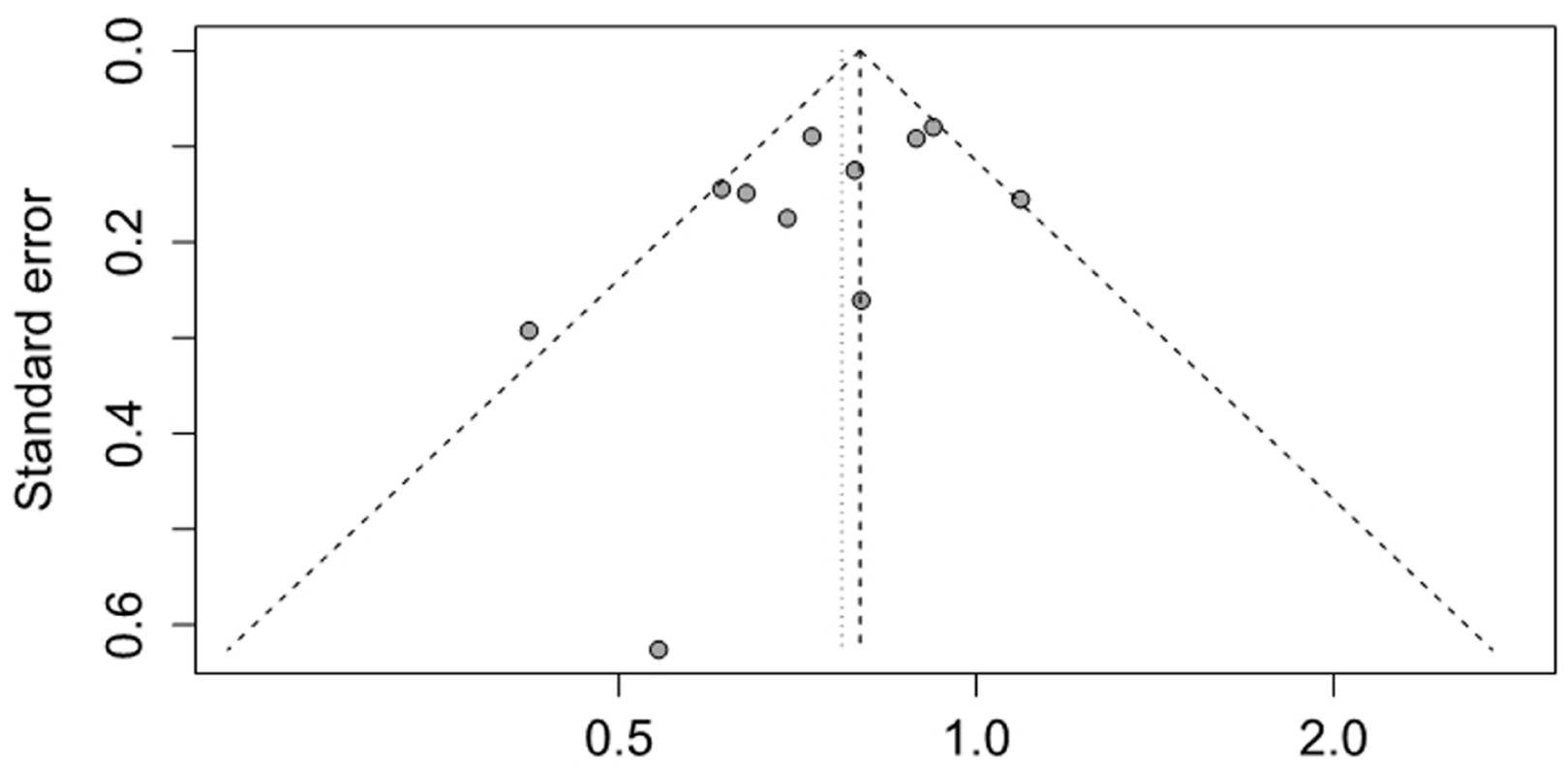

Hazard Ratio

Figure 3: Funnel plot of studies investigating association between metformin use and pancreatic cancer survival for cohort studies. 
the least, although we did not find significant publication bias for metformin subset in cohort studies, we could not totally exclude potential impact of unpublished studies on the pooled results, which might have resulted in reporting bias. However, the adjusted estimates of the results using the trim and fill methods remained unchanged, indicating the stability of our analysis.
In summary, the results from this meta-analysis revealed that in cohort studies, metformin, not other ADMs was associated with improved OS in PC patients. However, due to limited number of studies investigating other ADMs, further large-scale studies are warranted to determine these associations.

\begin{tabular}{|c|c|c|c|c|}
\hline Study & Hazard Ratio & HR & $95 \%-\mathrm{Cl}$ & W(random) \\
\hline Lee (2016) & 7 & 0.98 & {$[0.72 ; 1.34]$} & $26.0 \%$ \\
\hline Choi (2016) & + & 0.78 & {$[0.54 ; 1.13]$} & $24.1 \%$ \\
\hline Tseng (Smoking cohort) (2013) & 1 & 3.04 & {$[1.37 ; 6.74]$} & $12.4 \%$ \\
\hline Tseng (Non-smoking cohort) (2013) & $\frac{1}{1}$ & 1.02 & {$[0.44 ; 2.38]$} & $11.5 \%$ \\
\hline Jeon $(2014)$ & 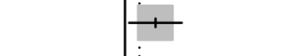 & 1.43 & {$[1.05 ; 1.95]$} & $26.0 \%$ \\
\hline $\begin{array}{l}\text { Random effects model } \\
\text { Heterogeneity: } 1 \text {-squared }=69 \%, p=0.0118\end{array}$ & & 1.18 & {$[0.83 ; 1.69]$} & $100 \%$ \\
\hline & 1 & & & \\
\hline 0.05 & 0.512 & & & \\
\hline
\end{tabular}

A

\begin{tabular}{|c|c|c|c|c|}
\hline Study & Hazard Ratio & $H R$ & \multicolumn{2}{|c|}{$95 \%-\mathrm{Cl} \mathrm{W}$ (random) } \\
\hline Lee (2016) & + & 1.14 & {$[0.86 ; 1.51]$} & $56.9 \%$ \\
\hline Choi (2016) & + & 0.89 & {$[0.64 ; 1.24]$} & $43.1 \%$ \\
\hline $\begin{array}{l}\text { Random effects model } \\
\text { Heterogeneity: I-squared }=17.9 \%\end{array}$ & 2696 & 1.03 & {$[0.81 ; 1.30]$} & $100 \%$ \\
\hline 更 & 1 & $T$ & & \\
\hline 0.05 & 0.512 & 1020 & & \\
\hline
\end{tabular}

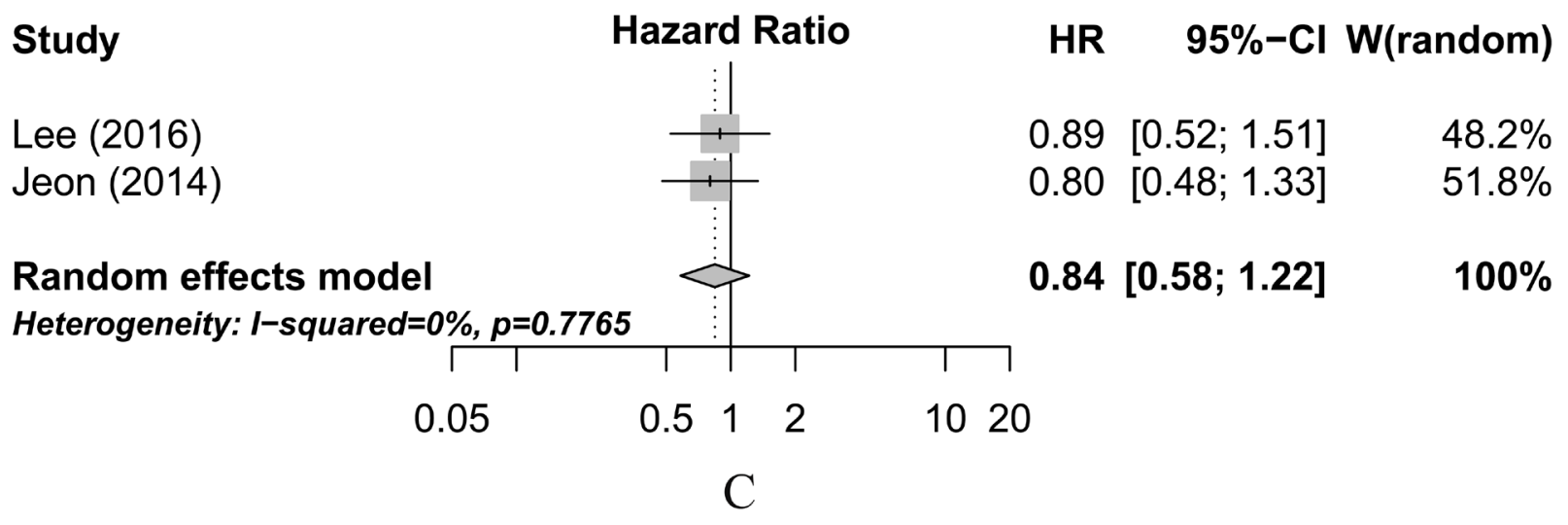

Figure 4: Meta-analysis of the associations between insulin (A), sulfonylureas (B), and thiazolidinediones (C) use and pancreatic cancer overall survival. CI, confidence interval; HR, hazard ratio; W (random): Weights (random effects model). 


\section{MATERIALS AND METHODS}

\section{Literature search and study selection}

Based on the PRISMA statement [24], we performed a comprehensive literature search in Pubmed and Embase databases up to August 2016 for relevant citations without language restrictions. We used the search strategies (Supplementary Table 2 and Table 3) that included Medical Subject Headings and Emtree headings combined key words relating to the prognostic effect of ADMs among PC patients. We also manually scanned the reference lists from the extracted relevant research papers, previous reviews and meta-analysis for additional possible publications.

We included published studies providing aggregate data if they met the following criteria: (1) evaluated any prognostic information in PC patients comparing ADMs users with non-users, (2) reported a summary statistic of hazard ratios (HRs) with $95 \%$ confidence intervals (CIs) or provided date for calculation as described by Parmar et al [25]. RCTs or observational studies were eligible for this meta-analysis. If there were more than one studies from the same cohort, we selected the most detailed or recent one for analysis. All the studies reporting prognostic information, including overall survival (OS), and progression-free survival (PFS), were selected in the main analyses (Supplementary Table 4). Two independent investigators (Zhou and Gong) conducted the study selection from eligible studies.

\section{Data extraction}

Two independent investigators (Zhou and Gong) selected articles and extracted data from eligible studies, evaluated the quality of each study and any discrepancies were resolved by a consensus discussion with a third investigator (Tan). The characteristics recorded were the first author's last name, publication year, country of the population studied, study design, study setting, number of hospitals involved, time period of study, information source for exposure ascertainment and outcome assessment, total number of persons in each group (exposed vs. not exposed), sample size, types of ADMs, stage, mean F/U (months), survival endpoints and adjustment variables $\mathrm{HR}$, and $95 \%$ confidence intervals (CIs) with adjustment for confounding factors. The methodological quality of each study was evaluated using the Newcastle-Ottawa quality assessment scale [26], in which three domains including cohort selection, comparability, and outcome were evaluated with a score range of 0 to 9 with nine representing the highest quality.

\section{Statistical analysis}

We used STATA statistical software (version 12.0, StataCorp LP, College Station, TX) and R statistical software (version 3.3.1) to perform the meta-analysis.
Survival estimates with full adjustments for known confounders of included studies were abstracted. Summary data reporting HRs with corresponding 95\% CIs estimated from Cox proportional hazards models were pooled with random-effects model [27]. The data regarding the association of ADMs (use vs. no use) with survival outcomes were pooled separately. We used the Cochrane $\mathrm{Q}$ statistic (with a $\mathrm{P}$ value less than 0.10 considering statistically significant) and the $I^{2}$ statistic (with an $I^{2}$ exceeding $50 \%$ indicating significant heterogeneity) to test for between-study heterogeneity [28]. Metformin usage and OS for PC patients were explored for primary meta-analysis. Other outcome measures such as PFS and Disease-free survival (DFS) were also evaluated. Owing to the limited studies for PFS and DFS, we combined the data of PFS and DFS as one outcome for the metaanalysis. We performed sensitivity analyses to explore the reasons for statistical heterogeneity. The risk of publication bias was assessed visually by inspecting of a funnel plot and statistically by using Egger's or Begg's regression model [29]. We further ascertained the number of missing studies using Duval and Tweedie's trim and fill method to adjust the summary hazard ratio based on all the studies including the hypothesized missing ones [30]. All statistical analyses were two-sided and a P-value less than 0.05 was considered significant.

\section{Abbreviations}

ADMs: anti-diabetic medications; SUs: sulfonylureas; TZDs: thiazolidinediones; DM: diabetes mellitus; PC: Pancreatic cancer; HRs: hazard ratios; CIs: confidence intervals; OS: overall survival; PFS: progression-free survival. RCTs: randomized controlled trials.

\section{CONFLICTS OF INTEREST}

The authors declare no competing financial interests.

\section{REFERENCES}

1. Siegel RL, Miller KD, Jemal A. Cancer statistics, 2016. CA Cancer J Clin. 2016; 66:7-30.

2. Ryan DP, Hong TS, Bardeesy N. Pancreatic adenocarcinoma. N Engl J Med. 2014; 371:1039-49.

3. Chiu CC, Huang CC, Chen YC, Chen TJ, Liang Y, Lin SJ, Chen JW, Leu HB, Chan WL. Increased risk of gastrointestinal malignancy in patients with diabetes mellitus and correlations with anti-diabetes drugs: a nationwide population-based study in Taiwan. Intern Med. 2013; 52:939-46.

4. Ben Q, Xu M, Ning X, Liu J, Hong S, Huang W, Zhang H, Li Z. Diabetes mellitus and risk of pancreatic cancer: A meta-analysis of cohort studies. Eur J Cancer. 2011; 47:1928-37. 
5. Huxley R, Ansary-Moghaddam A, Berrington de González A, Barzi F, Woodward M. Type-II diabetes and pancreatic cancer: a meta-analysis of 36 studies. Br J Cancer. 2005; 92:2076-83.

6. Kuuselo R, Savinainen K, Azorsa DO, Basu GD, Karhu R, Tuzmen S, Mousses S, Kallioniemi A. Intersex-like (IXL) is a cell survival regulator in pancreatic cancer with $19 \mathrm{q} 13$ amplification. Cancer Res. 2007; 67:1943-49.

7. Asano T, Yao Y, Shin S, McCubrey J, Abbruzzese JL, Reddy SA. Insulin receptor substrate is a mediator of phosphoinositide 3-kinase activation in quiescent pancreatic cancer cells. Cancer Res. 2005; 65:9164-68.

8. Lee SH, Yoon SH, Lee HS, Chung MJ, Park JY, Park SW, Song SY, Chung JB, Bang S. Can metformin change the prognosis of pancreatic cancer? Retrospective study for pancreatic cancer patients with pre-existing diabetes mellitus type 2. Dig Liver Dis. 2016; 48:435-40.

9. Kozak MM, Anderson EM, von Eyben R, Pai JS, Poultsides GA, Visser BC, Norton JA, Koong AC, Chang DT. Statin and Metformin Use Prolongs Survival in Patients With Resectable Pancreatic Cancer. Pancreas. 2016; 45:64-70.

10. Jang WI, Kim MS, Kang SH, Jo AJ, Kim YJ, Tchoe HJ, Park CM, Kim HJ, Choi JA, Choi HJ, Paik EK, Seo YS, Yoo $\mathrm{HJ}$, et al. Association between metformin use and mortality in patients with type 2 diabetes mellitus and localized resectable pancreatic cancer: a nationwide population-based study in korea. Oncotarget. 2017; 8:9587-96. https://doi. org/10.18632/oncotarget.14525.

11. Choi Y, Kim TY, Oh DY, Lee KH, Han SW, Im SA, Kim TY, Bang YJ. The Impact of Diabetes Mellitus and Metformin Treatment on Survival of Patients with Advanced Pancreatic Cancer Undergoing Chemotherapy. Cancer Res Treat. 2016; 48:171-79.

12. Cerullo M, Gani F, Chen SY, Canner J, Pawlik TM. Metformin Use Is Associated with Improved Survival in Patients Undergoing Resection for Pancreatic Cancer. J Gastrointest Surg. 2016; 20:1572-80.

13. Sadeghi N, Abbruzzese JL, Yeung SC, Hassan M, Li D. Metformin use is associated with better survival of diabetic patients with pancreatic cancer. Clin Cancer Res. 2012; 18:2905-12.

14. Reni M, Dugnani E, Cereda S, Belli C, Balzano G, Nicoletti R, Liberati D, Pasquale V, Scavini M, Maggiora P, Sordi V, Lampasona V, Ceraulo D, et al. (Ir)relevance of Metformin Treatment in Patients with Metastatic Pancreatic Cancer: An Open-Label, Randomized Phase II Trial. Clin Cancer Res. 2016; 22:1076-85.

15. Chaiteerakij R, Petersen GM, Bamlet WR, Chaffee KG, Zhen DB, Burch PA, Leof ER, Roberts LR, Oberg AL. Metformin Use and Survival of Patients With Pancreatic Cancer: A Cautionary Lesson. J Clin Oncol. 2016; 34:1898-904.
16. Kordes S, Pollak MN, Zwinderman AH, Mathôt RA, Weterman MJ, Beeker A, Punt CJ, Richel DJ, Wilmink JW. Metformin in patients with advanced pancreatic cancer: a double-blind, randomised, placebo-controlled phase 2 trial. Lancet Oncol. 2015; 16:839-47.

17. Amin S, Mhango G, Lin J, Boffetta P, Wisnivesky J, Lucas A. Metformin use does not improve survival among diabetics with pancreatic adenocarcinoma: A populationbased analysis. Am J Gastroenterol. 2015; 110:S17.

18. Hwang AL, Haynes K, Hwang WT, Yang YX. Metformin and survival in pancreatic cancer: a retrospective cohort study. Pancreas. 2013; 42:1054-59.

19. Jeon CY, Pandol SJ, Goodman MT. Survival time in pancreatic cancer patients with metabolic syndrome varies by use of insulin and statins. Cancer Res. 2014; 74:2173.

20. Tseng $\mathrm{CH}$. Diabetes, insulin use, smoking, and pancreatic cancer mortality in Taiwan. Acta Diabetol. 2013; 50:879-86.

21. Gallagher EJ, LeRoith D. Diabetes, cancer, and metformin: connections of metabolism and cell proliferation. Ann N Y Acad Sci. 2011; 1243:54-68.

22. Bowker SL, Majumdar SR, Veugelers P, Johnson JA. Increased cancer-related mortality for patients with type 2 diabetes who use sulfonylureas or insulin. Diabetes Care. 2006; 29:254-58.

23. Okumura T. Mechanisms by which thiazolidinediones induce anti-cancer effects in cancers in digestive organs. J Gastroenterol. 2010; 45:1097-102.

24. Moher D, Liberati A, Tetzlaff J, Altman DG, PRISMA Group. Preferred reporting items for systematic reviews and meta-analyses: the PRISMA statement. Int J Surg. 2010; 8:336-41.

25. Parmar MK, Torri V, Stewart L. Extracting summary statistics to perform meta-analyses of the published literature for survival endpoints. Stat Med. 1998; $17: 2815-34$.

26. Stang A. Critical evaluation of the Newcastle-Ottawa scale for the assessment of the quality of nonrandomized studies in meta-analyses. Eur J Epidemiol. 2010; 25:603-05.

27. van Houwelingen HC, Arends LR, Stijnen T. Advanced methods in meta-analysis: multivariate approach and metaregression. Stat Med. 2002; 21:589-624.

28. Higgins JP, Thompson SG. Quantifying heterogeneity in a meta-analysis. Stat Med. 2002; 21:1539-58.

29. Egger M, Davey Smith G, Schneider M, Minder C. Bias in meta-analysis detected by a simple, graphical test. BMJ. 1997; 315:629-34.

30. Duval S, Tweedie R. Trim and fill: A simple funnel-plotbased method of testing and adjusting for publication bias in meta-analysis. Biometrics. 2000; 56:455-63. 